\title{
A comparative study of amino acid consumption by rat islet cells and the clonal beta-cell line BRIN-BD11 - the functional significance of L-alanine
}

\author{
G Dixon ${ }^{1}$, J Nolan ${ }^{2}, \mathbf{N}$ McClenaghan ${ }^{3}$, P R Flatt ${ }^{3}$ and P Newsholme ${ }^{1}$ \\ 'Department of Biochemistry, Conway Institute of Biomolecular and Biomedical Research, University College Dublin, Belfield, Dublin 4, Ireland \\ ${ }^{2}$ Department of Endocrinology, St James's Hospital, Dublin 8, Ireland \\ ${ }^{3}$ School of Biomedical Sciences, University of Ulster, Coleraine, UK \\ (Requests for offprints should be addressed to P Newsholme; Email: philip.newsholme@ucd.ie)
}

\begin{abstract}
Evidence has been published that L-alanine may, under appropriate conditions, promote insulin secretion in normal rodent islets and various beta cell lines. Previous results utilising the clonal beta-cell line BRIN-BD11, demonstrated that alanine dramatically elevated insulin release by a mechanism requiring oxidative metabolism. We demonstrate in this paper that addition of $\mathrm{L}$-alanine had an insulinotropic effect in dispersed primary islet cells. Addition of D-glucose increased L-alanine consumption in both BRIN-BD11 cells and primary islet cells.
\end{abstract}

L-glutamine consumption in the BRIN-BD11 cell line and primary rat islets was also determined. The consumption rate was in line with that previously reported for cells of the immune system and other glutamine-utilising cells or tissues. However, L-alanine consumption was at least an order of magnitude higher than L-glutamine consumption. The metabolism of $\mathrm{L}$-alanine in the beta-cell may result in stimulation of insulin secretion via generation of metabolic stimulus secretion coupling factors such as L-glutamate.

Journal of Endocrinology (2003) 179, 447-454

\section{Introduction}

Amino acid metabolism, under appropriate conditions, is known to enhance insulin secretion from primary islet cells and beta-cell lines (Bratusch-Marrain et al. 1980, Charles et al. 1983, Yada 1994, Prentki 1996, Smith et al. 1997). L-alanine metabolism for example, is known to enhance insulin secretion alone or synergistically enhance glucosestimulated insulin secretion from the clonal beta-cell line BRIN-BD11 (Brennan et al. 2002). Other investigators, however, have not demonstrated an insulinotropic effect of L-alanine when added to rat islet cells (Sener \& Malaisse 2002). L-glutamine while readily consumed by beta-cells does not stimulate insulin secretion in the absence of allosteric activation of glutamate dehydrogenase (GDH). L-leucine may enhance L-glutamine-stimulated insulin secretion by acting as a GDH allosteric activator (Sener \& Malaisse 1980). In contrast to amino acids the key mechanism by which glucose enhances insulin secretion is known in considerable detail. Glucose enters the cell by facilitated diffusion, is converted by the glycolytic pathway to pyruvate and subsequently via pyruvate dehydrogenase (PDH) to acetyl CoA or via pyruvate carboxylase (PC) to oxaloacetate. Approximately equal amounts of pyruvate are utlised by the latter two enzymes (MacDonald 1993,
Khan et al. 1996, Schuit et al. 1997). After subsequent conversion to citrate the glucose carbon can be fully oxidised to $\mathrm{CO}_{2}$ in the citrate (TCA) cycle (Wollheim 2000). This results in an increase in the ATP/ADP ratio, closure of ATP-sensitive $\mathrm{K}^{+}$channels, membrane depolarisation, opening of voltage-activated $\mathrm{Ca}^{2+}$ channels, $\mathrm{Ca}^{2+}$ influx, a rise in $\left[\mathrm{Ca}^{2+}\right]_{\mathrm{i}}$ and activation of the exocytotic machinery (Wollheim 2000). The opening of $\mathrm{Ca}^{2+}$ channels is intermittent, oscillating with the membrane potential and therefore results in oscillations of $\left[\mathrm{Ca}^{2+}\right]_{\mathrm{i}}$ (Santos et al. 1991, Gilon \& Henquin 1992) that in turn trigger oscillations of insulin secretion (Gilon et al. 1993).

To date, little comparative data exists on relative consumption rates of two key nutrients, L-glutamine and L-alanine, in islet cells and beta-cell lines. While transport and metabolism of D-glucose have been extensively studied, equivalent data for the insulinotropic amino acids are generally not available. However, we have previously reported detailed aspects of L-alanine metabolism in the clonal cell line BRIN-BD11 (Brennan et al. 2002). While we determined routes of metabolism and quantitatively important end-products, we did not report rates of consumption of this amino acid. The present study has determined the relative consumption rates of $\mathrm{L}$-alanine 
and L-glutamine by primary islet cells and the clonal beta-cell line BRIN-BD11, further examined L-alanine consumption in the presence and absence of $\mathrm{D}$-glucose and assessed the impact of the amino acid on insulin secretion. L-alanine has previously been reported to be oxidised in islet cells (Sener \& Malaisse 2002) and BD11 cells (Brennan et al. 2002) while the first enzyme responsible for its metabolism, alanine aminotransferase, has a high activity in purified rat islet beta-cells (Sener et al. 2001). It is likely therefore that L-alanine metabolism is functionally significant in the beta-cell.

Our results suggest that L-alanine is consumed at extremely high rates by both the clonal beta-cell line and by rat islets. The functional significance of the high rates of L-alanine consumption is discussed.

\section{Materials and Methods}

Culture of BRIN-BD11 cells

Clonal insulin-secreting BRIN-BD11 cells were maintained in RPMI-1640 tissue culture medium with 10\% (v/v) foetal calf serum (FCS), $0 \cdot 1 \%$ antibiotics $(100 \mathrm{U} / \mathrm{ml}$ penicillin and $0.1 \mathrm{mg} / \mathrm{ml}$ streptomycin) and $11.1 \mathrm{mmol} / \mathrm{l}$ D-glucose, $\mathrm{pH} 7 \cdot 4$. The cells were maintained at $37^{\circ} \mathrm{C}$ in a humidified atmosphere of $5 \% \mathrm{CO}_{2}$ and $95 \%$ air using a Forma Scientific incubator (Marietta, OH, USA). The cells were cultured in 50-70 $\mathrm{ml}$ of tissue culture medium in T175 sterile tissue culture flasks.

\section{Culture of rat islets}

Female Wistar, 8-10 weeks old, were obtained from the Biomedical Facility, University College Dublin. Islet cells were obtained by collagenase digestion of the pancreas as previously described (Appels et al. 1989). The islets were kept in culture for 1-3 days in RPMI-1640 medium supplemented with $10 \% \mathrm{FCS}, 0 \cdot 1 \%$ antibiotics $(100 \mathrm{U} / \mathrm{ml}$ penicillin and $0.1 \mathrm{mg} / \mathrm{ml}$ streptomycin) and $11.1 \mathrm{mmol} / 1$ D-glucose, $\mathrm{pH} 7 \cdot 4$. Islets were subsequently hand picked and placed into individual wells of a 24-well plate.

\section{Insulin secretion}

For evaluation of insulin secretion, BRIN-BD11 cells or islets were seeded into 24 -well multiplates at $1.0 \times 10^{5}$ cells/well; islets were seeded at 30 islets/well. After overnight culture the medium was removed gently and cells washed twice with $1 \mathrm{ml}$ Krebs Ringer bicarbonate buffer (KRB; $115 \mathrm{mM} \mathrm{NaCl}, 4.7 \mathrm{mM} \mathrm{KCl}, 1.28 \mathrm{mM}$ $\mathrm{CaCl}_{2}, \quad 1.2 \mathrm{mM} \quad \mathrm{KH}_{2} \mathrm{PO}_{4}, \quad 1.2 \mathrm{mM} \quad \mathrm{MgSO}_{4} \cdot 7 \mathrm{H}_{2} \mathrm{O}$, $10 \mathrm{mM} \mathrm{NaHCO}, 5 \mathrm{~g} / 1 \mathrm{BSA}, \mathrm{pH} 7 \cdot 4$ ). After the final wash $1 \mathrm{ml} \mathrm{KRB}$ was added containing $1 \cdot 1 \mathrm{mM}$ D-glucose. After a $40 \mathrm{~min}$ preincubation at $37^{\circ} \mathrm{C}$, buffer was removed and the cell monolayers were incubated in the same buffer containing either $1.1 \mathrm{mM}$ D-glucose alone or supplemented with $10 \mathrm{mM}$ L-alanine. After $20 \mathrm{~min}$ incubation at $37^{\circ} \mathrm{C}$, an aliquot $(900 \mu \mathrm{l})$ of buffer was removed from each well and centrifuged at $500 \mathrm{~g}$ for $5 \mathrm{~min}$ at $4{ }^{\circ} \mathrm{C}$. The supernatant was stored at $-20^{\circ} \mathrm{C}$ for subsequent measurement of insulin by Mercodia Ultrasensitive rat insulin ELISA (Uppsala, Sweden), according to the manufacturer's instructions. Cell density and insulin content were not significantly different for any of the incubation conditions.

\section{Alanine consumption determination}

BRIN-BD11 cells were seeded into T25 sterile tissue flasks $\left(4 \times 10^{6}\right.$ cells per flask; final volume $\left.5 \mathrm{ml}\right)$ and islets were seeded into 24 -well plates (30 islets/well; final volume $500 \mu \mathrm{l})$. The cells were incubated for $24 \mathrm{~h}$ after which time the medium was removed and the cells were preincubated at $37^{\circ} \mathrm{C}$ in $\mathrm{KRB}$ supplemented with $1.1 \mathrm{mmol} / 1$ glucose for $40 \mathrm{~min}$. The cells were subsequently incubated in $1.1 \mathrm{mmol} / 1 \mathrm{D}$-glucose with either $0.5,1,5$ or $10 \mathrm{mmol} / \mathrm{l}$ L-alanine for $60 \mathrm{~min}$ or $16.7 \mathrm{mmol} / 1 \mathrm{D}$-glucose with $0.5,1,5$ or $10 \mathrm{mmol} / 1$ L-alanine for $60 \mathrm{~min}$ (BRIN-BD11 cell incubation volume $5 \mathrm{ml}$; islet cell incubation volume $500 \mu \mathrm{l}$ ). The L-alanine concentration was determined before and after the 60 min incubation period by the oxidation of $\mathrm{L}$-alanine to pyruvate and ammonia in the presence of NAD and alanine dehydrogenase. The increase in absorbance at $339 \mathrm{~nm}$ due to the formation of NADH is a measure of the amount of L-alanine present. The consumption of L-alanine after a $20 \mathrm{~min}$ incubation period in KRB supplemented with $1.1 \mathrm{mmol} / \mathrm{l} \mathrm{D}$-glucose and $10 \mathrm{mM}$ L-alanine by BRIN-BD11 cells $\left(2 \times 10^{7} /\right.$ T175 flask; final incubation volume $10 \mathrm{ml})$ and islets $(150$ islets/well; final incubation volume $500 \mu \mathrm{l}$ ) were also determined. The consumption of L-alanine (10 mmol/l) in RPMI-1640supplemented medium by BRIN-BD11 cells $\left(4 \times 10^{6} \%\right.$ T25 flask; final volume $5 \mathrm{ml}$ ) over $24 \mathrm{~h}$ was also determined.

\section{Glutamine consumption determination}

For evaluation of L-glutamine consumption, BRIN-BD11 cells were seeded into T25 sterile tissue flasks $\left(4 \times 10^{6}\right.$ cells/flask; final incubation volume $5 \mathrm{ml}$ ) and islets were seeded into 24 -well plates (30 islets/well; final incubation volume $500 \mu \mathrm{l})$. The glutamine concentration was determined at $0 \mathrm{~h}$ and then again after a $24 \mathrm{~h}$ incubation period by its hydrolysis to glutamate and ammonium ions in a reaction catalysed by asparaginase. The ammonium ions were then reacted with $\alpha$-ketoglutarate in the presence of $\mathrm{NADH}$ to form glutamate, $\mathrm{NAD}^{+}$and water. The concentration of glutamine in the sample was quantified indirectly by measuring the decrease in absorbance at $340 \mathrm{~nm}$ due to the conversion of NADH to $\mathrm{NAD}^{+}$. The 
amount consumed over $24 \mathrm{~h}$ was converted to absolute amounts and expressed as $\mu \mathrm{mol} / \mathrm{mg}$ protein $/ \mathrm{h}$.

\section{ATP and glutamate determinations}

BRIN-BD11 cells were seeded into T175 sterile tissue flasks $\left(2 \times 10^{7}\right.$ cells per flask) and islets were seeded into 24-well plates (150 islets/well). After a $48 \mathrm{~h}$ incubation period the medium was removed and the cells were preincubated at $37^{\circ} \mathrm{C}$ in $\mathrm{KRB}$ supplemented with $1.1 \mathrm{mmol} / 1$ glucose for $40 \mathrm{~min}$. The cells were subsequently incubated in $1.1 \mathrm{mmol} / 1 \mathrm{D}$-glucose with or without $10 \mathrm{mmol} / 1 \mathrm{~L}$-alanine for $20 \mathrm{~min}$ (BRIN-BD11 cells final incubation volume $10 \mathrm{ml}$, islets final incubation volume $500 \mu \mathrm{l})$. Medium was removed and cells were immediately frozen by brief exposure to liquid nitrogen. Cells were extracted with 6\% PCA and debris was removed from the flask using a cell scraper. After centrifugation, the supernatant was neutralised with $\mathrm{KOH}$. The ATP concentration in the supernatant was determined as described by Trautschold et al. (1985). Cellular glutamate concentration was quantified using a glutamate dehydrogenase-based assay kit supplied by Roche Diagnostics (Lewes, Sussex, UK).

\section{Protein determination}

Protein determination was by the Bradford method (Bradford 1976). For BRIN-BD11 the conversion factor for cell number to $\mathrm{mg}$ protein was $8.9 \times 10^{6} \mathrm{cells} / \mathrm{mg}$ protein and for islets this was $2.7 \times 10^{3}$ cells $/ \mathrm{mg}$ protein.

\section{Statistical analysis and protein determination}

Results are expressed as means \pm S.D. Analysis was performed by Student's $t$-test. $P<0 \cdot 05$ was considered to be statistically significant.

\section{Results}

\section{Nutrient consumption in BRIN-BD11 beta cells and islets}

In the present study the consumption of L-glutamine over $24 \mathrm{~h}$ (from a standard incubation concentration of $2 \mathrm{mmol} / \mathrm{l}$ in RPMI-1640) and L-alanine (from an excepted insulinotropic incubation concentration of $10 \mathrm{mmol} / \mathrm{l}$ ) over 20 mins by BRIN-BD11 cells or islets were determined. The consumption of L-alanine was substantially greater than L-glutamine for both BRINBD11 cells and rat islets, therefore requiring different incubation periods to optimise the respective assays so as to obtain reproducible results. The cellular utilisation of L-glutamine adjusted to a rate describing consumption over $1 \mathrm{~h}$ by islets was substantial $(0 \cdot 288 \pm 0 \cdot 036 \mu \mathrm{mol} / \mathrm{mg}$
Table 1 Consumption rates of L-glutamine and L-alanine by BRIN-BD11 beta cell and rat islets. Results are expressed as means \pm S.D. for 5-6 independent experiments

\begin{tabular}{llll} 
& $\begin{array}{l}\text { BRIN-BD11 cells } \\
(\mu \mathrm{mol} / \mathrm{mg} \text { protein })\end{array}$ & & $\begin{array}{l}\text { Islets } \\
(\mu \mathrm{mol} / \mathrm{mg} \text { protein })\end{array}$ \\
\cline { 2 - 2 } $\begin{array}{l}\text { L-Glutamine }(2 \mathrm{mmol} / \mathrm{l}) \\
\text { Consumption } / \mathrm{h}\end{array}$ & $0.219 \pm 0.024$ & & $0.288 \pm 0.036^{*}$ \\
$\begin{array}{l}\text { L-Alanine }(10 \mathrm{mmol} / \mathrm{l}) \\
\text { Consumption } / 20 \mathrm{~min}\end{array}$ & $2.01 \pm 0.37$ & & $7.79 \pm 2.79^{\S}$ \\
& & \\
\hline
\end{tabular}

Statistically significant differences in nutrient consumption rates (Student's $t$-test) between BRIN-BD11 cells and islets are indicated by ${ }^{\S} P<0 \cdot 001$, ${ }^{*} P<0 \cdot 05$. D-glucose concentration was $11 \cdot 1 \mathrm{mM}$ in the RPMI 1640 medium used for the L-glutamine determinations, whereas D-glucose was $1.1 \mathrm{mM}$ in the incubation medium used for the L-alanine determinations.

protein/h) and significantly higher $(P<0 \cdot 05)$ than that by the clonal BRIN-BD11 cells $(0 \cdot 219 \pm 0 \cdot 024 \mu \mathrm{mol} / \mathrm{mg}$ protein/h) (Table 1).

A striking finding was that L-alanine was consumed at extremely high rates by both BRIN-BD11 cells $(2.01 \pm 0.37 \mu \mathrm{mol} / \mathrm{mg}$ protein $/ 20$ mins $)$ and rat islets $(7.79 \pm 2.79 \mu \mathrm{mol} / \mathrm{mg}$ protein $/ 20 \mathrm{mins}$ ) (Table 1$)$. In BRIN-BD11 cells L-alanine (initial incubation concentration of $10 \mathrm{mM}$ ) was consumed at a rate at least an order of magnitude greater than that of L-glutamine (initial incubation concentration of $2 \mathrm{mM}$ ). In islets the rate of L-alanine consumption was also at least an order of magnitude greater than that of $\mathrm{L}$-glutamine. However preculture of BRIN-BD11 cells for $24 \mathrm{~h}$ in RPMI medium supplemented with $10 \mathrm{mM}$ L-alanine substantially reduced L-alanine consumption measured over a subsequent $20 \mathrm{~min}$ acute incubation period (results not shown).

\section{Effect of glucose on L-alanine consumption}

L-alanine consumption increased on addition of D-glucose for both BRIN-BD11 beta-cells (Fig. 1) and islets (Fig. 2). To gain further insight into the L-alanine consumption rates under these conditions, kinetic experiments were performed which required the use of L-alanine at several different concentrations including $0.5 \mathrm{mM}$, therefore the incubation period was extended to $1 \mathrm{~h}$ to ensure reproducibility of results in the L-alanine consumption assay. The $\mathrm{V}_{\max }$ for $\mathrm{L}$-alanine consumption by BRIN-BD11 cells increased $60 \%$ on addition of $16.7 \mathrm{mM}$ glucose as determined by intercept on the $1 / \mathrm{V}$ axis (Fig. 1).

There was a $26 \%$ increase in the $\mathrm{V}_{\max }$ for L-alanine consumption in rat islets following a similar increment in glucose concentration (Fig. 2). Apparent $\mathrm{K}_{\mathrm{m}}$ for L-alanine consumption was calculated to be $4.5 \mathrm{mM}$ in the presence of $1.1 \mathrm{mM}$ glucose and $4.9 \mathrm{mM}$ in the presence of $16.7 \mathrm{mM}$ glucose for BRIN-BD11 cells. In rat islets the apparent $\mathrm{K}_{\mathrm{m}}$ for L-alanine consumption was $2.8 \mathrm{mM}$ in 


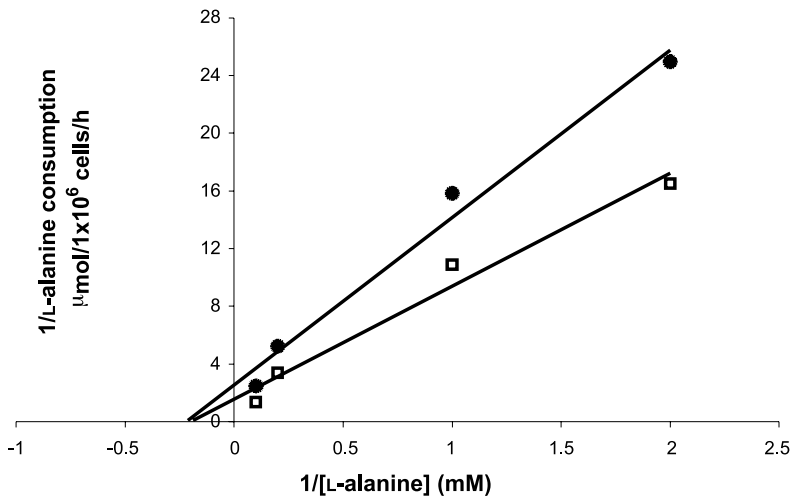

Figure 1 Lineweaver-Burk plot of the effect of D-glucose on the consumption of L-alanine by BRIN-BD11 beta cells. Rates of L-alanine consumption by BRIN-BD11 cells were measured after $60 \mathrm{~min}$ at various concentrations of L-alanine $(0 \cdot 5,1,5$ or $10 \mathrm{mM})$ in the presence of $1.1 \mathrm{mM} \bullet$ or $16.7 \mathrm{mM}$ D-glucose $\square$. Results are presented as mean for six separate experiments.

the presence of $1.1 \mathrm{mM}$ glucose and $3.0 \mathrm{mM}$ in the presence of $16.7 \mathrm{mM}$ glucose. These results suggest that glucose increases L-alanine consumption in both BRIN-BD11 cells and rat islets possibly by increasing transport rates rather than the apparent $\mathrm{K}_{\mathrm{m}}$ for the amino acid.

\section{Effect of L-alanine on insulin secretion}

In a previous study L-alanine was shown to be the most potent amino acid insulin secretagogue in the BRIN-BD11 cell line (McClenaghan et al. 1996). In the present study the basal rate of insulin secretion in BRIN-BD11 cells at $1.1 \mathrm{mM}$ glucose was $1.32 \mathrm{ng} /$ $1 \times 10^{6}$ cells $/ 20 \mathrm{~min}$ and addition of $10 \mathrm{mM}$ L-alanine

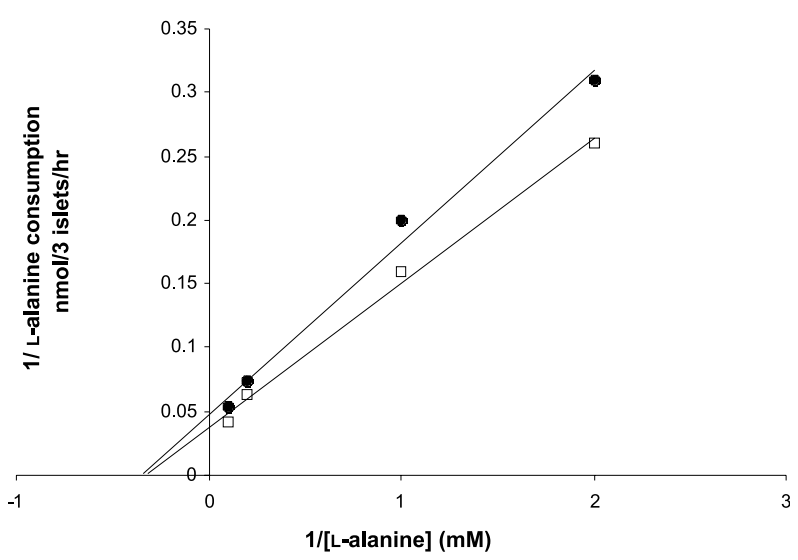

Figure 2 Lineweaver-Burk plot of the effect of D-glucose on the consumption of $\mathrm{L}$-alanine by islets. Rates of $\mathrm{L}$-alanine consumption by islets were measured after $60 \mathrm{~min}$ at various concentrations of L-alanine $(0 \cdot 5,1,5$ or $10 \mathrm{mM})$ in the presence of $1 \cdot 1 \mathrm{mM} \bullet$ or $16.7 \mathrm{mM}$ D-glucose $\square$. Results are presented as mean for six separate experiments. produced a significant $(P<0 \cdot 001) 3$-fold increase (Fig. 3). There was also a significant $(P<0 \cdot 05)$ positive effect on insulin secretion from dispersed rat islet cells (treated with trypsin to produce single cells) when treated with $10 \mathrm{mM}$ $\mathrm{L}$-alanine in the presence of $1.1 \mathrm{mM}$ glucose (Fig. 3).

\section{Effect of $\mathrm{L}$-alanine on cellular ATP and glutamate concentration}

Addition of $10 \mathrm{mM}$ L-alanine significantly reduced the ATP content of BRIN-BD11 cells $(P<0.05)$ and that of rat islet cells $(P<0 \cdot 05)$, determined after $20 \mathrm{~min}$ of incubation (Table 2). However, addition of $10 \mathrm{mM}$ L-alanine significantly increased $(P<0.001)$ the intracellular BRIN-BD11 cellular glutamate concentration by $2 \cdot 3$-fold and the rat islet glutamate concentration by $1 \cdot 8$-fold after $20 \mathrm{~min}(P<0 \cdot 01$, Table 2$)$.

\section{Discussion}

Glucose is consumed at high rates by primary rat islet cells and BRIN-BD11 cells in vitro (Brennan et al. 2002). Glucose metabolism is closely correlated with insulin secretion in the pancreatic beta-cell (Henquin 2000). L-glutamine is known to be an important nutrient fuel for a number of rapidly dividing cells (e.g. enterocytes, tumour cells, fibroblasts, reticulocytes; Lund 1980, Krebs 1981) and also resting lymphocytes and thymocytes, which have the potential for rapid cell division (Ardawi \& Newsholme 1983, Brand et al. 1984). L-glutamine is also an essential nutrient for cells such as macrophages and neutrophils, which, while they do not have a high proliferative potential, require high rates of protein synthesis and secretion (Newsholme 2001). In this study, we report that both rat islets and BRIN-BD11 cells consumed L-glutamine at high rates (Table 1). Islets may have a high rate of protein turnover even under basal conditions, which would require L-glutamine for purine and pyrimidine synthesis, subsequent mRNA production and in addition, protein synthesis. Remarkably L-alanine was consumed at significantly higher rates than glutamine in both BRIN-BD11 cells and rat islets (Table 1). Addition of $16.7 \mathrm{mM}$ glucose significantly enhanced $\mathrm{L}$-alanine consumption in both BRIN-BD11 beta-cells $(P<0 \cdot 01)$ and primary islet cells $(P<0 \cdot 05)$, suggesting a critical role for $\mathrm{L}$-alanine in beta-cell function.

A number of amino acids promote or synergistically enhance insulin release from pancreatic beta-cells (Fajans et al. 1967, McClenaghan et al. 1996). The mechanisms by which amino acids enhance insulin secretion are varied. The cationically charged amino acid, L-arginine, does so by direct depolarisation of the plasma membrane at neutral $\mathrm{pH}$ but only in the presence of glucose. Other amino acids, which are co-transported with $\mathrm{Na}^{+}$, can also depolarise the cell membrane as a consequence of $\mathrm{Na}^{+}$ 


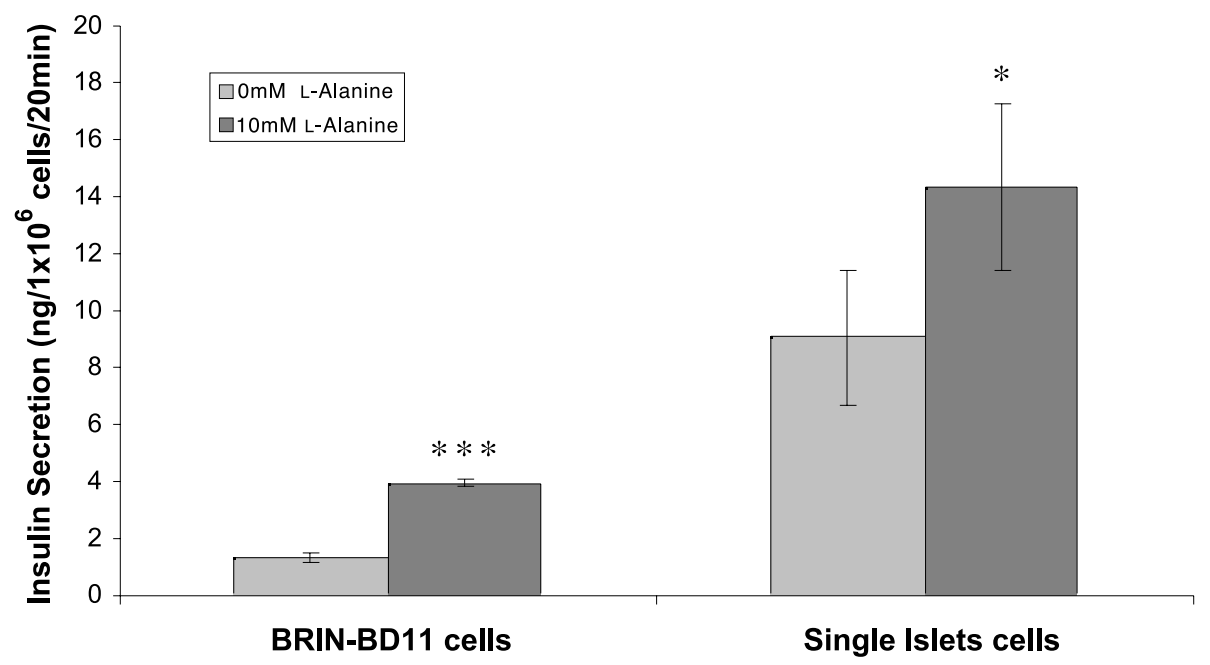

Figure 3 Effect of $10 \mathrm{mM}$ L-alanine on insulin secretion from BRIN-BD11 beta cells and single islet cells in the presence of $1 \cdot 1 \mathrm{mM}$ D-glucose. Results are expressed as means \pm S.D. for four independent experiments. ${ }^{* *} P<0 \cdot 001$ compared with insulin secretion in the absence of $10 \mathrm{mM}$ L-alanine. ${ }^{*} P<0.05$ compared with insulin secretion in the absence of $10 \mathrm{mM}$ L-alanine.

transport and thus induce insulin secretion by activating voltage-dependent calcium channels. Metabolism of amino acids, resulting in partial oxidation e.g. L-alanine (Brennan et al. 2002), may initially increase the cellular content of ATP, leading to closure of the ATP-sensitive $\mathrm{K}^{+}$channel, depolarisation of the plasma membrane, activation of voltage-activated $\mathrm{Ca}^{2+}$ channel, $\mathrm{Ca}^{2+}$ influx and insulin exocytosis. However it is possible to additionally stimulate insulin secretion via allosteric effects on regulatory proteins such as GDH (as described for leucine) (Malaisse-Lagae et al. 1982). After $20 \mathrm{~min}$ incubation in the presence of $10 \mathrm{mM}$ L-alanine there was a small but significant reduction in ATP content of BRIN-BD11 cells and rat islets (Table 2). This may have been due to activation of the $\mathrm{Na}^{+} / \mathrm{K}^{+}$ATPase which will be required to remove the $\mathrm{Na}^{+}$co-transported with L-alanine into the beta-cell.

A recent study has definitively demonstrated the importance of the oxidative metabolism of L-alanine to insulin secretion (Brennan et al. 2002). The respiratory poison, oligomycin, dramatically decreased alaninestimulated insulin secretion from BRIN-BD11 beta-cells. These investigators additionally provided ${ }^{13} \mathrm{C}-\mathrm{NMR}-$ based evidence for substantial oxidative L-alanine metabolism in the BRIN-BD11 cells. While metabolism of L-alanine was required for stimulation of insulin secretion, L-alanine also synergistically enhanced glucose metabolism and thus insulin secretion in BRIN-BD11 cells. Despite the many previous reports of the insulinotropic effect of L-alanine, there have been relatively few studies on utilisation rates of L-alanine by beta-cells (Hellman et al. 1971, Prentki \& Renold 1983). In the study by Hellman et al. (1971) the uptake of $\mathrm{L}-\left[\mathrm{U}_{-}{ }^{14} \mathrm{C}\right]$ alanine from obesehyperglycaemic mice was found to be concentration $(1 \cdot 0-25 \cdot 0 \mathrm{mM})$ and time (10-120 min) dependent. We have demonstrated in this paper, increased L-alanine consumption in the presence of glucose by both BRINBD11 cells and islets. In BRIN-BR11 cells, increasing the glucose concentration from 1.1 to $16.7 \mathrm{mM}$ in the presence of various L-alanine concentrations increased the

Table 2 Intracellular concentrations of L-glutamate and ATP in BRIN-BD11 cells and islets after a 20 min incubation in the presence or absence of $10 \mathrm{mM}$ L-alanine

\begin{tabular}{|c|c|c|c|c|}
\hline & $\begin{array}{l}\text { [D-glucose] } \\
(\mathrm{mM})\end{array}$ & $\begin{array}{l}\text { [L-alanine] } \\
(\mathrm{mM})\end{array}$ & $\begin{array}{l}\text { Glutamate } \\
\text { (nmol/mg protein) }\end{array}$ & $\begin{array}{l}\text { ATP } \\
\text { (nmol/mg protein) }\end{array}$ \\
\hline \multicolumn{5}{|l|}{ Cell type } \\
\hline BRIN-BD-11 & $1 \cdot 1$ & 0 & $63 \cdot 87 \pm 10 \cdot 42$ & $18 \cdot 90 \pm 1 \cdot 71$ \\
\hline BRIN-BD11 & $1 \cdot 1$ & 10 & $148 \cdot 90 \pm 20 \cdot 30^{\S}$ & $15 \cdot 53 \pm 1 \cdot 74^{*}$ \\
\hline ISLETS & $1 \cdot 1$ & 0 & $215 \cdot 66 \pm 30 \cdot 37$ & $52 \cdot 96 \pm 4.53$ \\
\hline ISLETS & $1 \cdot 1$ & 10 & $393 \cdot 65 \pm 68.09^{\#}$ & $44 \cdot 89 \pm 4 \cdot 34^{*}$ \\
\hline
\end{tabular}

Values are means \pm S.D. for four independent experiments.

${ }^{\star} P<0 \cdot 001,{ }^{\#} P<0 \cdot 01,{ }^{*} P<0 \cdot 05$ compared with same cell type without L-alanine. 


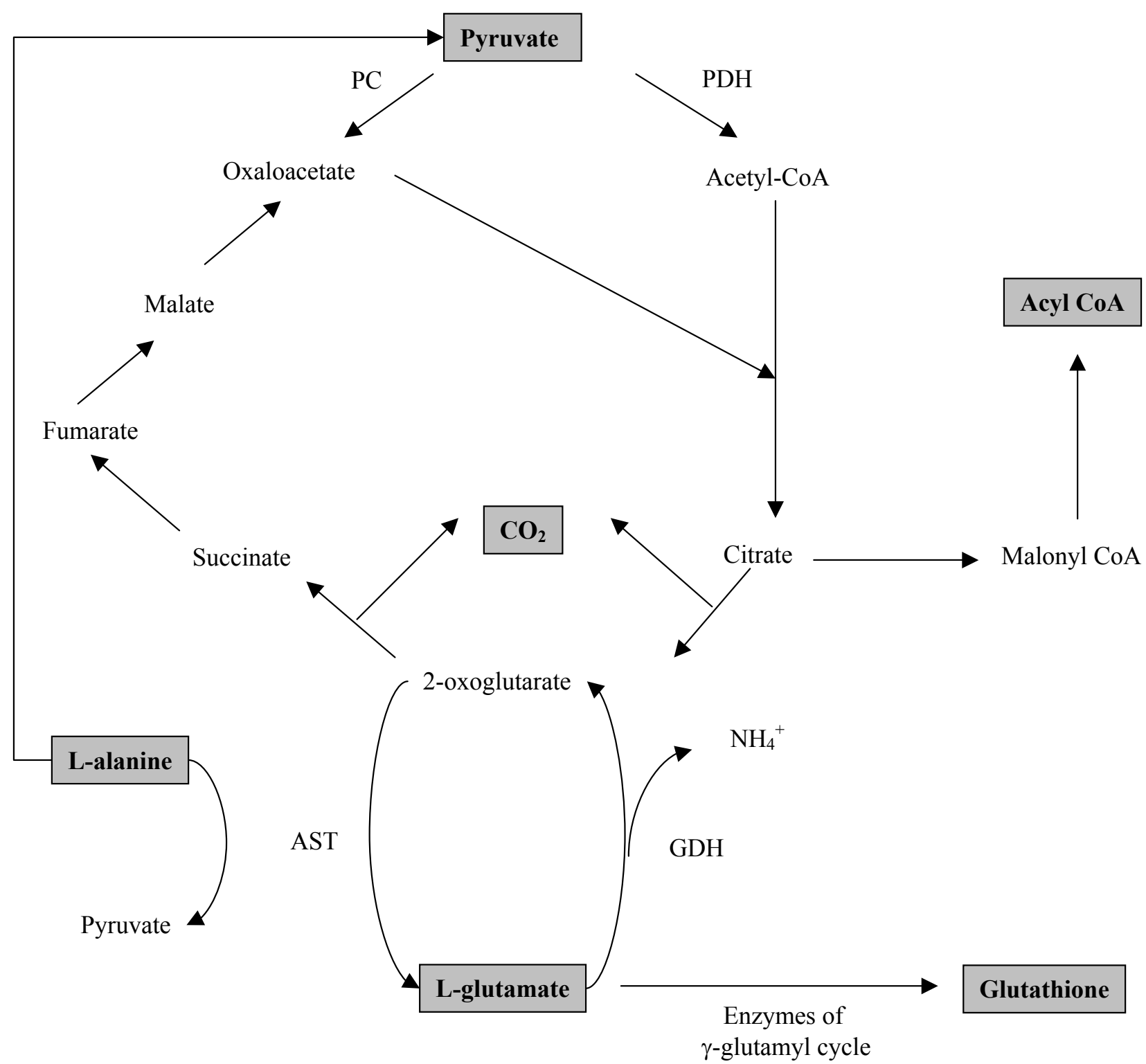

Figure 4 L-alanine metabolism in the beta cell. ALT, alanine aminotransferase; GDH, glutamate dehydrogenase; PC, pyruvated carboxylase; $\mathrm{PDH}$, pyruvate dehydrogenase.

$\mathrm{V}_{\max }$ for L-alanine consumption by $60 \%$ from 3.51 to $5.62 \mu \mathrm{mol} / \mathrm{mg}$ protein/h (Fig. 1). However the increased consumption of L-alanine cannot be correlated with an increase in alanine oxidation as demonstrated using ${ }^{13} \mathrm{C}-$ NMR in BRIN-BD11 cells (Brennan et al. 2002). It is possible L-alanine may be converted to metabolic stimulus-secretion coupling factors which do not require oxidation. Increased L-alanine consumption may increase the intracellular concentration of specific stimulussecretion metabolic coupling factors via enhanced mitochondrial metabolism due to an elevation in intracellular $\mathrm{Ca}^{2+}$. The $\mathrm{Ca}^{2+}$ dependence of a number of mitochondrial metabolic steps connected with TCA cycle activity (McCormack \& Denton 1980, Civelek et al. 1996) would support such a hypothesis. Thus insulin secretion would be promoted. The most likely metabolic coupling factor would be L-glutamate, generated by the alanine aminotransferase reaction:

L-Alanine +2 -oxoglutarate $\rightarrow$ L-Glutamate + pyruvate

The pyruvate produced may subsequently be converted to oxaloacetate by PC and then enzymes of the TCA cycle to 2-oxoglutarate to provide substrate for the reaction 
shown above (see Fig. 4 for further details). Thus, a significant increase in the cellular content of L-glutamate, originating from $\mathrm{L}$-alanine, can occur as reported here after a $20 \mathrm{~min}$ incubation (Table 2) and as previously described after a $1 \mathrm{~h}$ incubation in the presence of L-alanine (Brennan et al. 2002). Glutamate has previously been shown to act as a metabolic stimulus secretioncoupling factor in glucose-stimulated insulin secretion in islet and beta-cell lines (Maechler \& Wollheim 1999, Rubi et al. 2001, Hoy et al. 2002, Broca et al. 2003). While evidence for a direct stimulatory role of L-glutamate on insulin secretion is controversial (MacDonald \& Fahien 2000, Bertrand et al. 2002 ) we have recently reported that L-glutamate can be converted to glutathione in the betacell via reactions of the gamma glutamyl cycle, indirectly regulating insulin secretion (Brennan et al. 2003).

The results of this study add weight to the hypothesis that L-alanine is an important beta-cell fuel in vitro and in vivo. In vivo L-alanine may be produced from L-glutamine metabolism (primary fuel for intestinal epithelia - Newsholme et al. 2003) and secreted by the intestinal epithelial cells. It may reach $0 \cdot 1-1 \cdot 0 \mathrm{mM}$ concentrations in the hepatic vein and may thus be important for regulation of beta cell function by nutrients.

\section{Acknowledgements}

This work was generously supported by a Health Research Board of Ireland Research Project Grant. We thank Mr. Paul Rooney, Department of Biochemistry, University College Dublin, for technical assistance.

\section{References}

Appels B, Burkart V, Kantwerk-Funke G, Funda J, Kolb-Bachofen V \& Kolb H 1989 Spontaneous cytotoxicity of macrophages against cultured pancreatic islet cells. Journal of Immunology 142 3803-3808.

Ardawi MS \& Newsholme EA 1983 Glutamine metabolism in lymphocytes of the rat. Biochemical Journal $212835-842$.

Bertrand G, Ishiyama N, Nenquin M, Ravier MA \& Henquin J-C 2002 The elevation of glutamate content and the amplification of insulin secretion in glucose-stimulated pancreatic islets are not causally related. Journal of Biological Chemistry 277 32883-32891.

Bradford MM 1976 A rapid and sensitive method for the quantitation of microgram quantities of protein utilising the principle of proteindye binding. Analytical Biochemistry 72 248-254.

Brand K, Williams JF \& Weidemann MJ 1984 Glucose and glutamine metabolism in rat thymocytes. Biochemical Journal 221 471-475.

Bratusch-Marrain P, Ferenci P \& Waldhausl W 1980 Leucine assimilation in patients with diabetes mellitus. Acta Endocrinologica 93 461-465.

Brennan L, Shine A, Hewage C, Malthouse JPG, Brindle KM, McClenaghan N, Flatt PR \& Newsholme P 2002 A nuclear magnetic resonance-based demonstration of L-alanine metabolism and L-alanine-enhanced glucose metabolism in a clonal pancreatic $\beta$-cell line. Diabetes 51 1714-1721.

Brennan L, Corless M, Hewage C, Malthouse JPG, McClenaghan $\mathrm{NH}$, Flatt PR \& Newsholme P $2003{ }^{13} \mathrm{C}$ NMR analysis reveals a link between L-glutamine metabolism, D-glucose metabolism and $\gamma$-glutamyl cycle activity in a clonal pancreatic $\beta$-cell line. Diabetologia. 46 1503-1512.

Broca C, Brennan L, Petit P, Newsholme P \& Maechler P 2003 Mitochondria-derived glutamate at the interplay between branchedchain amino acid and glucose-induced insulin secretion. FEBS Letters 545 167-172.

Charles S \& Henquin JC 1983 Distinct effects of various amino acids on ${ }^{45} \mathrm{Ca}^{2+}$ fluxes in rat pancreatic islets. Biochemical Journal 214 899-917.

Civelek VN, Deeney JT, Shalosky NJ, Tornheim K, Hansford RG, Prentki M \& Corkey BE 1996 Regulation of pancreatic $\beta$-cell mitochondrial metabolism: influence of $\mathrm{Ca}^{2+}$, substrate and ADP. Biochemical Journal 318 615-621.

Fajans SS, Floyd JC Jr, Knopf RF, Guntsche EM, Rull JA, Thiffault CA \& Conn JW 1967 A difference in mechanisms by which leucine and other amino acids induce insulin release. Journal of Clinical Endocrinology and Metabolism 27 1600-1606.

Gilon P \& Henquin JC 1992 Influence of membrane potential changes on cytoplasmic $\mathrm{Ca}^{2+}$ concentration in an electrically excitable cell, the insulin-secreting pancreatic $\beta$-cell. Journal of Biological Chemistry 267 20713-20720.

Gilon P, Shepherd RM \& Henquin JC 1993 Oscillations of secretion driven by oscillations of cytoplasmic $\mathrm{Ca}^{2+}$ as evidenced in single pancreatic islets. Journal of Biological Chemistry 268 22265-22268.

Hellman B, Sehlin J \& Taljedal IB 1971 Uptake of alanine, arginine and leucine by mammalian pancreatic $\beta$ cells. Endocrinology $\mathbf{8 9}$ $1432-1439$.

Henquin JC 2000 Triggering and amplifying pathways of regulation of insulin secretion by glucose. Diabetes 49 1751-1760.

Hoy M, Maechler P, Efanov AM, Wollheim CB, Berggren P-O \& Gromada J 2002 Increase in cellular glutamate levels stimulates exocytosis in pancreatic beta cells. FEBS Letters $\mathbf{5 3 1}$ 199-203.

Khan A, Ling ZC \& Landau BR 1996 Quantifying the carboxylation of pyruvate in pancreatic islets. Journal of Biological Chemistry 271 2539-2542.

Krebs HA 1981 In Glutamine: Metabolism Enzymology and Regulation, pp 319-329. Eds J Mora \& R Palacios. New York: Academic Press.

Lund P 1980 Glutamine metabolism in the rat. FEBS Letters 117 K86-K92.

McClenaghan NH, Barnett CR, O'Harte FPM \& Flatt PR 1996 Mechanisms of amino acid-induced insulin secretion from the glucose-responsive BRIN-BD11 pancreatic $\beta$-cell line. Journal of Endocrinology 15 349-357.

McCormack JG \& Denton RM 1980 Role of calcium ions in the regulation of intramitochondrial metabolism. Properties of the $\mathrm{Ca}^{2+}$-sensitive dehydrogenases within intact uncoupled mitochondria from the white and brown adipose tissue of the rat. Biochemical Journal 190 95-105.

MacDonald MJ 1993 Glucose enters mitochondrial metabolism via both carboxylation and decarboxylation of pyruvate in pancreatic islets. Metabolism 42 1229-1231.

MacDonald MJ \& Fahien LA 2000 Glutamate is not a messenger in insulin secretion. Journal of Biological Chemistry 275 34025-34027.

Maechler P \& Wollheim CB 1999 Mitochondrial glutamate acts as a messenger in glucose-induced insulin exocytosis. Nature $\mathbf{4 0 2}$ 595-596.

Malaisse-Lagae F, Sener A, Garcia-Morales P, Valverde I \& Malaisse WJ 1982 The stimulus-secretion coupling of amino acid-induced insulin release. Influence of a nonmetabolized analog of leucine on the metabolism of glutamine in pancreatic islets. Journal of Biological Chemistry 257 3754-3758. 
Newsholme P 2001 Why is L-glutamine metabolism important to cells of the immune system in health, postinjury, surgery or infection? Journal of Nutrition 131 2515-2522.

Newsholme P, Procopio J, Ramos Lima MM, Pithon-Curi TC \& Curi R 2003 Glutamine and glutamate: their central role in cell metabolism and function. Cell Biochemistry and Function 21 1-9.

Prentki M 1996 New insights into pancreatic beta-cell metabolic signalling in insulin secretion. European Journal of Endocrinology 134 272-286.

Prentki M \& Renold AE 1983 Neutral amino acid transport in isolated rat pancreatic islets. Journal of Biological Chemistry 258 14239-14244.

Rubi B, Ishihara H, Hegardt FG, Wollheim CB \& Maechler P 2001 GAD65-mediated glutamate decarboxylation reduces glucosestimulated insulin secretion in pancreatic beta cells. Journal of Biological Chemistry 276 36391-36396.

Santos RM, Rosario LM, Nadal A, Garcia-Sancho J, Soria B \& Valdeolmillos M 1991 Widespread synchronous $\left[\mathrm{Ca}^{2+}\right]_{\mathrm{i}}$ oscillations due to bursting electrical activity in single pancreatic islets. Pflugers Archiv 418 417-422.

Schuit F, De Vos A, Farfari S, Moens K, Pipeleers D, Brun T \& Prentki M 1997 Metabolic fate of glucose in purified islet cells: glucose-regulated anaplerosis in beta cells. Journal of Biological Chemistry 272 18572-18579.

Sener A \& Malaisse WJ 1980 L-leucine and a nonmetabolized analogue activate pancreatic islet glutamate dehydrogenase. Nature 288 187-189.
Sener A \& Malaisse WJ 2002 The stimulus-secretion coupling of amino acid-induced insulin release. Insulinotropic action of L-alanine. Biochimica et Biophysica Acta 1573 100-104.

Sener A, Mercan D \& Malaisse WJ 2001 Enzymatic activities in two populations of purified rat islet beta-cells. International Journal of Molecular Medicine 8 285-289.

Smith PA, Shakura H, Coles B, Gummerson N, Proks P \& Ashcroft FM 1997 Electrogenic arginine transport mediates stimulus-secretion coupling in mouse pancreatic $\beta$-cells. Journal of Physiology 499 625-635.

Trautschold I, Lamprecht W \& Schweitzer G 1985 ATP:UV-method with hexokinase and glucose-6-phosphate dehydrogenase. In Methods of Enzymatic Analysis, edn 3, vol VII, pp 346-357. Eds HU Bergmeyer. Germany: VCH.

Wollheim CB 2000 Beta-cell mitochondria in the regulation of insulin secretion: a new culprit in type II diabetes. Diabetologia 43 265-277.

Yada T 1994 Action mechanisms of amino acids in pancreatic $\beta$-cells. In Frontiers of Insulin Secretion and Pancreatic $\beta$-Cell Research, pp 129-135. Eds PR Flatt \& S Lenzen. London: Smith-Gordon.

Received 6 August 2003

Accepted 1 September 2003

Made available online as an

Accepted Preprint 9 September 2003 